\title{
Nepalese landslide information system (NELIS): a conceptual framework for a web-based geographical information system for enhanced landslide risk management in Nepal
}

\author{
Sansar Raj Meena, Florian Albrecht, Daniel Hölbling, Omid Ghorbanzadeh, and Thomas Blaschke \\ Interfaculty Department of Geoinformatics - Z_GIS, University of Salzburg, Salzburg, Austria \\ Correspondence: Omid Ghorbanzadeh (omid.ghorbanzadeh@stud.sbg.ac.at)
}

Received: 27 July 2019 - Discussion started: 31 July 2019

Revised: 24 November 2020 - Accepted: 15 December 2020 - Published: 26 January 2021

\begin{abstract}
Comprehensive and sustainable landslide risk management, including the identification of areas susceptible to landslides, requires responsible organisations to collaborate efficiently. Landslide risk management efforts are often made after major triggering events, such as hazard mitigation after the 2015 Gorkha earthquake in Nepal. There is also a lack of knowledge sharing and collaboration among stakeholders to cope with major disaster events, in addition to a lack of efficiency and continuity. There should be a system to allow for landslide information to be easily updated after an event. For a variety of users of landslide information in Nepal, the availability and extraction of landslide data from a common database are a vital requirement. In this study, we investigate the requirements to propose a concept for a web-based Nepalese landslide information system (NELIS) that provides users with a platform to share information about landslide events to strengthen collaboration. The system will be defined as a web GIS (geographic information system) that supports responsible organisations in addressing and managing different user requirements of people working with landslides, thereby improving the current state of landslide hazard and risk management in Nepal. The overall aim of this study is to propose a conceptual framework and design of NELIS. A system like NELIS could benefit stakeholders involved in data collection and landslide risk management in their efforts to report and provide landslide information. Moreover, such a system would allow for detailed and structured landslide documentation and consequently provide valuable information regarding susceptibility and hazard and risk mapping. For the reporting of land-
\end{abstract}

slides directly to the system, a web portal is proposed. Based on field surveys, a literature review and stakeholder interviews, a structure of the landslide database and a conceptual framework for the NELIS platform are proposed.

\section{Introduction}

Landslides are one of the significant hazards that cause fatalities and damages in the Himalayas. About $70 \%$ of Nepal's total area is mountainous terrain and prone to landslides (Hasegawa et al., 2009; Kargel et al., 2016). One of the most severe landslide events in recent years happened as a result of the Gorkha earthquake in April 2015. The earthquake had a magnitude of $M 7.8$ and caused landslides in an area of $10000 \mathrm{~km}^{2}$ located in Nepal and China, which led to property damage and about 9000 human fatalities (Kargel et al., 2016; Tsou et al., 2018). As Nepal is located in the IndoEurasian tectonic zone, it is prone to earthquakes. In addition to earthquake-induced landslides, heavy rainfalls during the monsoon season trigger landslides every year (Zhang et al., 2019). Many of the earthquake-induced landslides get reactivated and extended during the monsoon rains and lead to the destruction of infrastructure and human losses (Zhang et al., 2019). Due to a high population growth rate and unplanned dense building activities in susceptible areas, there is an increase in damage (Dikshit et al., 2020). Limited investments in slope protection and the absence of spatial planning reveal the lack of intervention measures for reducing the land- 
slide risk in Nepal. As a consequence, the socio-economic problems of Nepal's mountainous regions are growing due to landslides, including loss of agricultural fields, erosion and homelessness due to building damage.

In response to the landslides in the Gorkha earthquake context, the authorities in Nepal realised that their management of the landslide hazard and associated risk mitigation programmes has to improve both at the regional and national scale (Nepal et al., 2018; Bisri and Beniya, 2016). There are several reasons why current processes are insufficient. First, efficiency is hindered by the low level of collaboration that exists between the authorities in charge of landslide risk management in Nepal. This sometimes leads to duplicated efforts in landslide documentation because of uncoordinated responsibilities. Second, and as a consequence, the information basis for landslide risk management is heterogeneous and dispersed over different organisations. Typically, access to landslide inventories is limited to internal users, as most of the inventories are published in the form of reports.

Moreover, each organisation follows its own rules for collecting landslide information; i.e. they do not follow standardised approaches or guidelines for data collection. This heterogeneity also contributes to a lack of information exchange and hinders collaboration because the landslide information of one organisation may not fulfil another organisation's requirements (Meena et al., 2018). In addition to public authorities, some scientific organisations also address landslide risk management, mainly focusing on testing new landslide documentation with remote sensing. For example, the Tribhuvan University and the International Centre for Integrated Mountain Development (ICIMOD) have prepared preearthquake (Pokharel and Bhuju, 2015) and post-earthquake (Gurung and Maharjan, 2016) landslide inventories for the Gorkha earthquake. However, their mapping approaches are not yet integrated into responsible authorities' documentation processes for ensuring that the resulting inventories comply with the authorities' requirements, e.g. concerning validation procedures for data verification. A third reason why current landslide risk management practices are insufficient is the mode in which management efforts are carried out. They are often implemented after major triggering events only, such as recovery measures taken after the 2015 Gorkha earthquake in Nepal. This approach mostly favours reactive measures but omits a proactive perspective on landslide risk management. Additionally, the poor state of availability and accessibility of landslide information in Nepal limits the quality of landslide hazard assessments. Most landslide information is available either in analogue reports, or the organisations cannot share the information with others.

Further, landslide risk management in Nepal may not exploit input from all relevant stakeholders yet. At the local level, residents that are affected by landslides are the primary source of landslide information. In rural areas, the residents often report the events to the local police or other authorities. However, currently, there are not enough efforts to in- volve local people in landslide hazard and risk management in Nepal (Meena et al., 2018). Some important efforts exist such as the Nepal Disaster Risk Reduction Portal, which collects information related to floods, earthquakes, landslides, fire, drought, avalanches and heavy rainfall events and keeps information in the form of tables in the portal. The public can visit the Nepal Disaster Risk Reduction (NDRR) web portal and get information about a specific location related to the date of the incident, damage, missing people and estimated loss (Linkha, 2020).

In all, landslide risk management in Nepal involves many organisations that collaborate little with each other and have to work with a heterogeneous and dispersed basis of landslide information (Meena et al., 2018). Organisations responsible for disaster risk management are working at their own departmental levels and for their organisational interests such as the Department of Local Infrastructure Development and Agricultural Roads (DoLIDAR), which collects data about road blockage due to slope failures in the form of analogue data. Similarly, the Department of Water Induced Disaster Management (DWIDM) collects data related to waterinduced disasters in the watersheds. Efforts regarding landslide risk management mostly are event-triggered and lack a proactive perspective. Consequently, current processes tend to lack efficiency and cannot provide continuity for the entire landslide risk management cycle of mitigation, preparedness, response and recovery.

In Nepal, there is a need for a consistent landslide information database, i.e. a landslide inventory, as part of a collaboration platform that is accessible to all organisations involved in landslide risk management and that is embedded within well-organised landslide risk management processes. Hosted by a comprehensive nodal agency, the platform could significantly increase the awareness of landslides. It would also enable improved susceptibility analysis and enhance hazard evaluation and risk assessment credibility. Such a platform would provide researchers and policymakers with an updatable database to prepare landslide zonation of the country and identify susceptible regions. Therefore, it would allow for better spatial planning for mitigation of future hazards. Moreover, with a quick enough documentation process, the platform would even support organising remedial actions to reconstruct infrastructure in affected areas.

To achieve such a solution, landslide risk management organisations in Nepal could exploit opportunities provided by processes and state-of-the-art technologies from the wider natural hazards domain that are already applied in other countries or that are currently being researched. In the natural hazards domain, endeavours are made to generate landslide inventory databases for triggering events such as earthquakes (Roback et al., 2018). The international Emergency Events Database (EM-DAT) lists events where at least 10 people died or at least 100 people were affected (CRED, 2018). The United Nations Office for Disaster Risk Reduction (UNISDR) has set up DesInventar Sendai as a tool for record- 
ing disaster loss data for the member countries, and it directly addresses "the SFDRR [Sendai Framework for Disaster Risk Reduction] targets A, B, C and D which aims at reducing the human fatalities, number of people affected, financial losses and infrastructural damages by the year 2030" (Panwar and Sen, 2020).

Van Den Eeckhaut and Hervás (2012) carried out a study in Europe that shows the status of landslide databases and the value in attaining landslide susceptibility hazard and risk analysis. It indicates that a total of 25 European Union members maintain national landslide databases. In another effort, Herrera et al. (2018) analysed the landslide databases from the European countries' geological surveys by concentrating on their interoperability and completeness. In general, geological surveys are most often responsible for creating landslide databases in their country; for example, France's digital landslide database was developed by the French Geological Society already in 1994. Some countries have more than one landslide database; e.g. Italy has two, the Inventory of Landslide Phenomena in Italy (IFFI) (Lazzari et al., 2018) and the AVI project (Vulnerable Italian Areas) (Guzzetti et al., 1994). In the United Kingdom, there is a national landslide database (Pennington et al., 2015) developed by the British Geological Survey (BGS). As of 2015, it has point- and polygonbased landslide information with attributes attached for each landslide and covers approximately 17000 records of landslides. Recently, national landslide databases have been developed, for example, for China (Xu et al., 2015) and New Zealand (Rosser et al., 2017). In the USA, landslide inventory data are managed by the United States Geological Survey (USGS). India, a developing country, has Bhuvan, a geoportal platform for providing visualisation services and Earth observation (EO) data to users in the public domain. Remote sensing data are available for public and organisational usage, and there is basic GIS (geographic information system) functionality with many thematic maps on display functions. Landslide data in India are collected by the Geological Survey of India (GSI) along with the National Remote Sensing Centre (NRSC).

Web technologies and information-processing functionality can facilitate the use of landslide inventories in landslide risk management. A comprehensive web-based landslide inventory can include various additional data, such as aerial photographs, satellite data, monitoring data and attribute information (Chen et al., 2016). Several landslide inventory preparation techniques can be considered: visual satellite image interpretation (Cheng et al., 2018; Roback et al., 2018), semi-automated image analysis techniques (Hölbling et al., 2012), machine learning models (Tavakkoli Piralilou et al., 2019; Fang et al., 2020), deep learning approaches and convolution neural networks (Ghorbanzadeh et al., 2019b), mapping based on unmanned aerial vehicles (UAVs) (Suwal and Panday, 2015; Rossi et al., 2018), use of tablet-based GIS (De Donatis and Bruciatelli, 2006; Knoop and van der Pluijm, 2006), and involvement of local com- munities as an alternative approach (Jaiswal and van Westen, 2013; Carr, 2014; Devkota et al., 2014). Landslide inventory databases provide the base data for carrying out susceptibility analysis using multiple knowledge-based and data-driven models at various spatial levels from regional to national levels (Hölbling et al., 2018; Meena et al., 2019). Ideally, for every landslide, the accessible data will be transferred to one central database so that clients can retrieve, include, update or expel information in an automated way (Klose et al., 2014). Web-based landslide inventory databases provide vital baseline information about landslide areas, location, types, triggers, geometry, distribution and a broad scope of extra attributes (Guzzetti et al., 2012).

For Nepal, we suggest developing the Nepalese landslide information system (NELIS) to report and arrange landslide data. NELIS would make landslide data available to all relevant government agencies as well as the public. NELIS would also allow for the reporting of landslides directly in the system through a web portal connected to a central database for storing landslide information.

This study aims to conceptualise a web-based landslide information system that supports coordinated landslide action in Nepal and the development of a consistent landslide database. We propose NELIS's conceptual framework and analyse related user requirements, thereby presenting a starting point for technical implementation. Section 2 presents the methods for identifying stakeholders and for performing interviews according to a questionnaire. Further, it explains how we analyse the responses to understand the stakeholder's existing workflows and develop user needs and requirements for NELIS. The methods section concludes by presenting the steps to identify system architecture components for and the user interaction with NELIS. Accordingly, Sect. 3 presents the results and discussion. Section 3.1 includes an overview of the stakeholders involved in Nepal's landslide risk management and their motives for collecting landslide information. We present a complementary overview of the state of currently available landslide documentation coming out of mapping efforts done in the past. In Sect. 3.2, we present the stakeholders' needs and requirements towards a collaboration platform, and we design the appropriate workflows for landslide documentation supported by a platform like NELIS. Finally, in Sect. 3.3, we propose a system architecture that supports the functionalities required by NELIS. Section 4 presents the conclusion.

\section{Methods}

Service development yields the best results when users with their needs and preferences are involved in the design process (Saffer, 2017). To develop a concept for NELIS, we, therefore, adopted a user-centred design (UCD) approach. According to Wealands et al. (2007), UCD follows a sequence of tasks: understanding and specifying the user's working 
context, defining the user requirements, producing the design solution, and evaluating the design. Albrecht et al. (2016) already applied UCD for developing an EO-based landslide web service for the landslide community in Austria. This study for proposing the NELIS concept followed steps similar to Albrecht et al. (2016) for UCD, adapted for Nepal's situation.

\subsection{Collecting information about users}

For collecting information about users and their needs and requirements, we prepared a questionnaire survey addressing the stakeholders that are active in landslide risk management in Nepal. Further, we performed a field trip to visit relevant stakeholder organisations at their premises and to conduct interviews. Additional information about the stakeholders and their workflows related to landslide risk management was available through their web presentations and the body of literature on landslide research in Nepal. The main opportunity for establishing contacts with stakeholders and for distributing the questionnaire was our participation in the workshop "Scientific learning exchange on landslide management and bio-engineering in Nepal: from data to landslide mitigation new venues for collaboration", which was organised by the Nepali government's Department of Soil Conservation and Watershed Management (DSCWM) in Kathmandu, Nepal, in summer 2015. Most of the stakeholders active in landslide risk management in Nepal and representatives of the landslide research community were present. This included governmental authorities, both on the national and district levels; non-governmental organisations (NGOs) working in the natural hazards domain and infrastructure management; research organisations; international organisations like the United Nations Development Programme (UNDP) and ICIMOD; and other local Nepalese organisations. From the more than 80 participants, we received 40 answers to our questionnaire survey. Furthermore, we visited eight organisations at their premises for detailed interviews to better understand their organisational structure and how they collect information on natural hazards at the local level.

The questionnaire survey used in this study collected information about the respondent's organisation and the respondent's role within the organisation. Besides, it posed four open questions related to landslide risk management in Nepal as a basis for identifying user needs and requirements. The first question related to the functions and components of a landslide database that are important and needed to be prioritised. It asked which functions and components would be important when implementing a Nepalese landslide information system. The answering options pointed out the four main functions of "reporting", "data collecting", "mapping" and "updating datasets". The respondents were allowed to select one or more of the functions. The second question allowed for open answers and asked people to explain their choice from the first question, i.e. why or why not did they think a particular function needs to be prioritised. The third question allowed for open answers and asked how the respondent would contribute to a landslide information system or the development of it and with which components. The fourth question again allowed for open answers and asked the respondents about the main challenges they see in establishing NELIS.

The personal interviews conducted with stakeholders allowed for asking detailed questions that focused on understanding the stakeholders' responsibilities, information needs and NELIS requirements. In case we identified knowledge gaps in our understanding of the stakeholders' context later in the analysis process, we consulted the stakeholder's web presentation or called the stakeholders for follow-up verification.

\subsection{Analysis of information input}

Based on the above-described process for information collected from the stakeholders, we carried out a stakeholder analysis and identified user needs and requirements. The stakeholder analysis covered governmental authorities with a role in landslide risk management from all of Nepal's appropriate administrative levels. Further, the analysis included national and international non-governmental organisations, research institutes, and other stakeholders from the public.

As landslide information about the past constitutes an important basis for any future studies, we present a table of the existing landslide inventories and analogue registries that stakeholders have produced for Nepal or selected regions of Nepal. For each inventory, we identify the producing organisation and if the documented landslides happened before, during or after the Gorkha earthquake. Further, we identify the number of landslides included in the inventory, the geometry type, the documentation process or method, the data used (e.g. very high-resolution (VHR) or high-resolution (HR) EO data), the covered area, and the literature reference or source. Besides, we describe the landslide documentation processes of selected organisations in more detail.

We performed an open-questionnaire survey with stakeholders and did interviews during field trips to stakeholder premises. We also collected existing information about stakeholders available from platforms like the Nepal Disaster Risk Reduction Portal, Ministry of Home Affairs, Nepal (http: //drrportal.gov.np/, last access: 15 December 2020). The answers of stakeholders were categorised according to their requirements. For some stakeholders, we only list them as representative of a broader category. The subsequent identification of user needs and requirements first defines scenarios where a user applies a system for a specific purpose. The scenarios are a narrative description of how a user interacts with a system to achieve their objective. We document the primary scenarios that NELIS shall fulfil. Out of the scenarios, we identify needs; for the needs, we assign user requirements. 


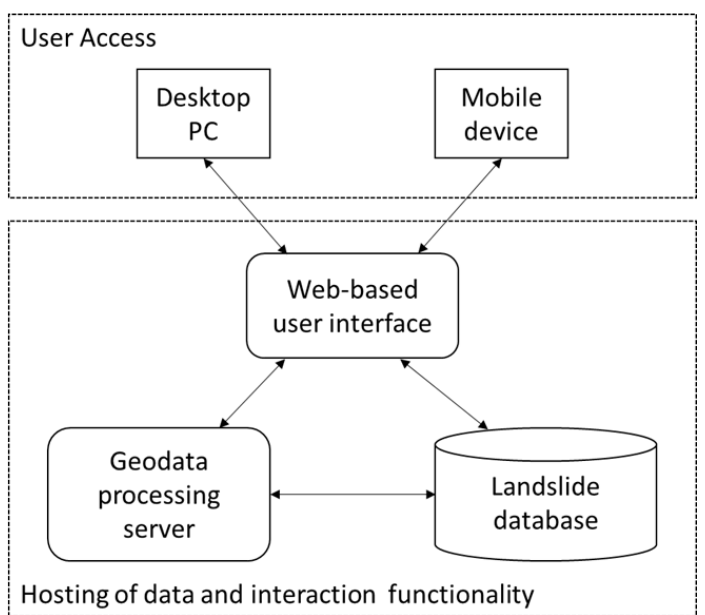

Figure 1. Conceptual structure for NELIS.

\subsection{Designing a conceptual framework for NELIS}

We used the gathered user needs and requirements to formulate the structure of NELIS based on information about stakeholders' requirements and the existing infrastructure of Information and Communications Technology (ICT) in Nepal, i.e. the Nepal Disaster Risk Reduction (NDRR) portal (http://drrportal.gov.np/, last access: 15 December 2020). The NDRR portal collects information related to floods, earthquakes, landslides, fire, drought, avalanches and heavy rainfall events and keeps information in the form of tables in the portal. The public can visit the NDRR web portal and get information about a specific location related to the date of the incident, damage, missing people, estimated loss, etc. We identified the system architecture components for the development of NELIS's conceptual structure and enhanced the present architecture of the portal, which only has data in tabular form and digital maps. The proposed structure is presented in Fig. 1.

Our approach to identifying the specific structural elements is to model user interaction workflows with NELIS with workflow diagrams. The diagrams identify the users, their steps in the process of landslide documentation, the required resources for input, the employed system components, stored datasets and related properties of data entries. Thereby, the database structure of NELIS could be formulated in detail.

\section{Results and discussion}

\subsection{Stakeholder overview and status of landslide risk management in Nepal}

\subsubsection{Stakeholder overview}

Figure 2 presents an overview of the relevant stakeholders that are involved in landslide risk management in Nepal. The stakeholders can be categorised into five main groups: governmental authorities, research institutions and academia, international organisations, news and media, and the public. According to the constitution of Nepal of 2015, Nepal is administratively divided into the federal government, provincial government and local government (Secretariat and Durbar, 2015).

The local level is subdivided into metropolitan cities and sub-metropolitan cities and rural and urban municipalities. The smallest administrative unit at the local level is the ward. Currently, there are eight provinces in Nepal, and the provincial level is subdivided into provincial ministries and district offices. At the federal level, there are subdivisions into ministries and national institutions. The national departments are related to soil conservation, forest management, urban planning and agricultural development. The National Disaster Risk Reduction and Management Authority (NDRRMA) is responsible for acting as a nodal agency for coordinating and managing disasters in Nepal (Bhandari and Hodder, 2019). In Nepal, the NDRRMA and the Ministry of Home Affairs are the central government's focal institutions for managing disasters (Nepal et al., 2018), while at the local level, there are central people for climate change and disaster in the municipalities, who coordinate at the local level with various sectoral offices. On the level of national departments, the stakeholders involved in landslide risk management in Nepal are interested in landslide information for various reasons. For example, landslides lead to land degradation and soil erosion and therefore are relevant for the Department of Soil Conservation and Watershed Management (DSCWM), the Department of Mines and Geology (DMG), and the Department of Water Induced Disaster Management (DWIDM). The DSCWM, the Department of Local Infrastructure Development and Agricultural Roads (DoLIDAR), and the Department of Hydrology and Meteorology (DHM) use landslide information as an input to landslide hazard mitigation planning. The Ministry of Energy, Water Resources and Irrigation; the Ministry of Forests and Environment; and the National Planning Community have an interest in landslides on the ministry level (Watson, 2017; Vij et al., 2020). Due to landslides' relevance to their work, many stakeholders have produced their landslide inventories for past landslide events (for more details, see Sect. 3.1.2). 


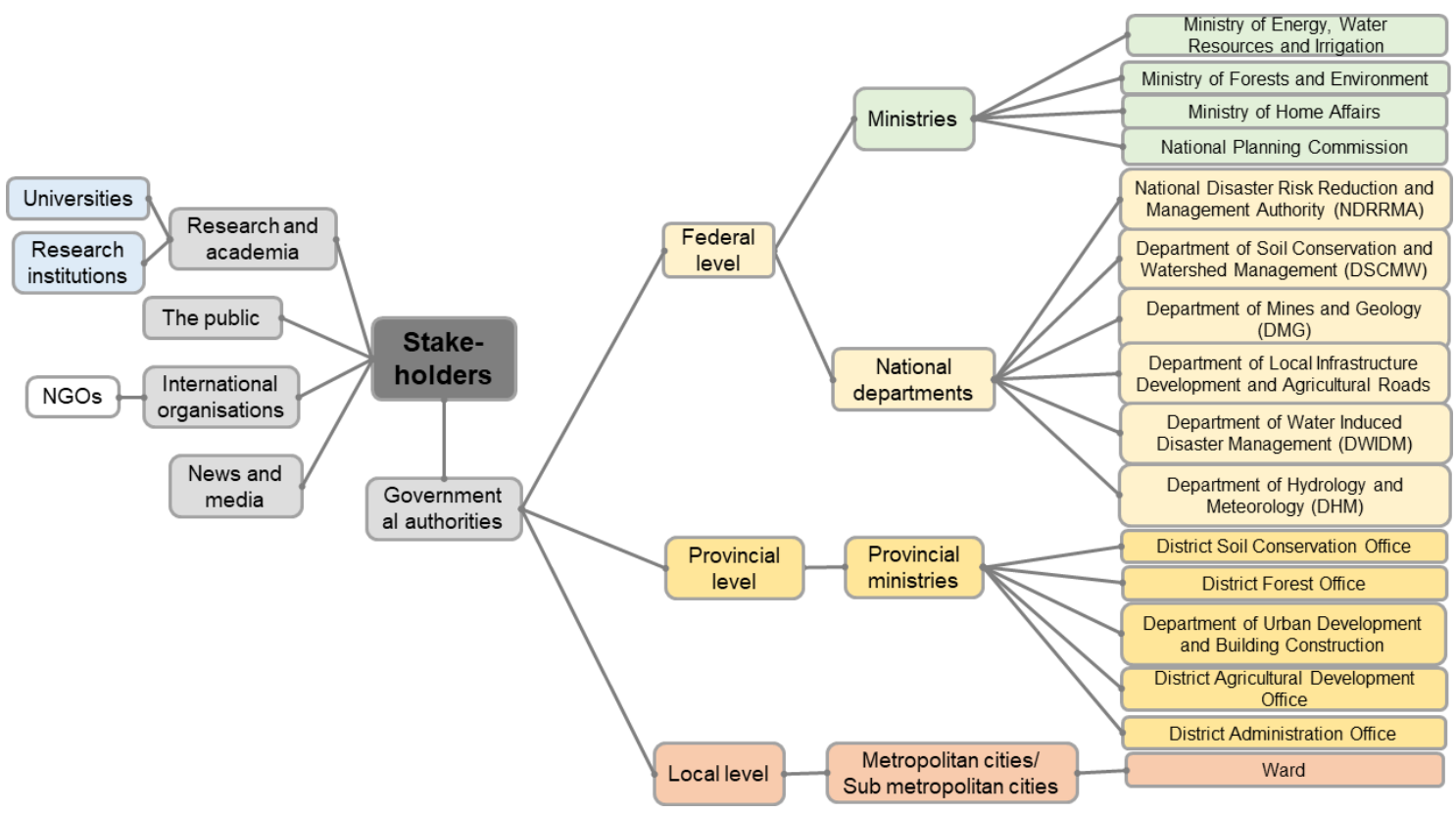

Figure 2. Stakeholder's overview and organisational structure in Nepal (Secretariat and Durbar, 2015).

\subsubsection{Landslide inventory data from stakeholders in Nepal}

Before the Gorkha earthquake, landslide inventories were prepared by the Tribhuvan University and the International Centre for Integrated Mountain Development (ICIMOD) (Pokharel and Bhuju, 2015) and other organisations such as the Department of Soil Conservation and Watershed Management (DSCWM), the Department of Mines and Geology (DMG), and the Department of Water Induced Disaster Management (DWIDM). After the Gorkha earthquake in 2015, several attempts were made by stakeholders to carry out landslide inventory mapping for the affected area of about $10000 \mathrm{~km}^{2}$ (Regmi et al., 2016; Martha et al., 2017; Robinson et al., 2017; Xu et al., 2017; Roback et al., 2018; Ghorbanzadeh et al., 2019a; Meena and Tavakkoli, 2019; Sharma et al., 2019; Tavakkoli Piralilou et al., 2019). Table 1 lists the landslide inventories created for Nepal. There is a variation in the number of landslides for the same event. Some of the inventories were accessed through the online portal of earthquake response, Humanitarian Data Exchange (HDX; 2015), and for the pre-earthquake inventories, authors were contacted for the data. Most inventories are polygon-based and hence enable the statistical analysis of area distribution for hazard analysis (Malamud et al., 2004). Other inventories are point-based and were compiled just after the earthquake by the ICIMOD (Gurung and Maharjan, 2016) and the BGS (Pennington et al., 2015).

There were several attempts made to map landslides by teams from, for example, the University of Arizona, Tucson, AZ, USA (Kargel et al., 2016); the NASA-USGS earth- quake response team (Roback et al., 2018); and the Chinese Academy of Sciences (Zhang et al., 2016). Gnyawali et al. (2016) mapped 19332 landslides using Google Earth imagery. Researchers from the Indian Space Research Organisation (ISRO) (Martha et al., 2017) mapped a total of 15551 landslides using object-oriented image classification. Valagussa et al. (2016) mapped 4300 coseismic landslides using Google Earth satellite images in a subregion of the affected area. Later, Roback et al. (2018) mapped 24915 landslides over most of the earthquake area. The large number of identified landslides is the result of using VHR WorldView satellite imagery. They also differentiated the source area and body of the landslides, which makes the inventory distinct from others. Three rainfall-induced landslide inventories were created based on data collected during fieldwork. Pre-earthquake landslides were mapped by Zhang et al. (2016) and by Pokharel and Bhuju (2015).

The different approaches applied to produce the abovedescribed landslide inventories include fieldwork, remotesensing-based methods and the harvesting of digital news articles. The fieldwork of local departments, such as the DMG and DSCWM, produced detailed field reports for landslide inventory creation (see Table 2). Different technical reports and information sheets for field data collection are available among different organisations. After the Gorkha earthquake, an initial assessment of earthquake-affected settlements was carried out by the DMG, DSCWM, DWIDM and Tribhuvan University. An example of an information sheet as used by the DSCWM is shown in Table 3. The information collected in the field is summarised in technical reports that provide details about the occurrence of a landslide (location and date), 
Table 1. Landslide inventories in Nepal.

\begin{tabular}{|c|c|c|c|c|c|c|}
\hline $\begin{array}{l}\text { Producing } \\
\text { organisation }\end{array}$ & $\begin{array}{l}\text { Inventory } \\
\text { description }\end{array}$ & sides & Geometry type & $\begin{array}{l}\text { Method of } \\
\text { inventory } \\
\text { generation }\end{array}$ & Area coverage & Reference \\
\hline $\begin{array}{l}\text { Department of } \\
\text { Civil Engineering, } \\
\text { Khwopa College } \\
\text { of Engineering, } \\
\text { Bhaktapur, Nepal }\end{array}$ & $\begin{array}{l}\text { After } 2015 \\
\text { Gorkha } \\
\text { earthquake }\end{array}$ & 19332 & Point & $\begin{array}{l}\text { Remote sensing } \\
\text { (visual } \\
\text { interpretation) } \\
\text { and field } \\
\text { verification }\end{array}$ & Central Nepal & $\begin{array}{l}\text { Gnyawali et al. } \\
\text { (2016) }\end{array}$ \\
\hline $\begin{array}{l}\text { Department of } \\
\text { Mines and Geology } \\
\text { (DMG) }\end{array}$ & NA & NA & NA & Fieldwork & Regional & $\begin{array}{l}\text { Analogue } \\
\text { reports }\end{array}$ \\
\hline $\begin{array}{l}\text { Department of } \\
\text { Soil Conservation } \\
\text { and Watershed } \\
\text { Management } \\
\text { (DSCWM) }\end{array}$ & NA & NA & NA & Fieldwork & Regional & $\begin{array}{l}\text { Analogue } \\
\text { reports }\end{array}$ \\
\hline $\begin{array}{l}\text { Tribhuvan } \\
\text { University }\end{array}$ & $\begin{array}{l}\text { Landslide } \\
\text { inventory } \\
\text { for whole ofNepal (pre- } \\
\text { earthquake) }\end{array}$ & 5003 & Point & $\begin{array}{l}\text { Remote sensing } \\
\text { (visual } \\
\text { interpretation) } \\
\text { and fieldwork }\end{array}$ & Whole of Nepal & $\begin{array}{l}\text { Pokharel and } \\
\text { Bhuju (2015) }\end{array}$ \\
\hline $\begin{array}{l}\text { ICIMOD (Koshi } \\
\text { River basin 1992) }\end{array}$ & $\begin{array}{l}\text { Landslide } \\
\text { inventory } \\
\text { for whole ofNepal (pre- } \\
\text { earthquake) }\end{array}$ & 3559 & Polygon & $\begin{array}{l}\text { Remote sensing } \\
\text { (visual } \\
\text { interpretation) }\end{array}$ & $\begin{array}{l}\text { Koshi River } \\
\text { basin }\end{array}$ & $\begin{array}{l}\text { Zhang et al. } \\
\text { (2016) }\end{array}$ \\
\hline $\begin{array}{l}\text { ICIMOD (Koshi } \\
\text { River basin 2010) }\end{array}$ & $\begin{array}{l}\text { Landslide } \\
\text { inventory } \\
\text { for whole of } \\
\text { Nepal (pre- } \\
\text { earthquake) }\end{array}$ & 3398 & Polygon & $\begin{array}{l}\text { Remote sensing } \\
\text { (visual } \\
\text { interpretation) }\end{array}$ & $\begin{array}{l}\text { Koshi River } \\
\text { basin }\end{array}$ & $\begin{array}{l}\text { Zhang et al. } \\
\text { (2016) }\end{array}$ \\
\hline $\begin{array}{l}\text { University of } \\
\text { Milano-Bicocca, } \\
\text { Italy }\end{array}$ & $\begin{array}{l}\text { After } 2015 \\
\text { Gorkha } \\
\text { earthquake }\end{array}$ & 4300 & Polygon & $\begin{array}{l}\text { Remote sensing } \\
\text { (visual } \\
\text { interpretation) }\end{array}$ & Central Nepal & $\begin{array}{l}\text { Valagussa et al. } \\
\text { (2016) }\end{array}$ \\
\hline $\begin{array}{l}\text { International } \\
\text { Centre for } \\
\text { Integrated } \\
\text { Mountain } \\
\text { Development } \\
\text { (ICIMOD) }\end{array}$ & $\begin{array}{l}\text { After } 2015 \\
\text { Gorkha } \\
\text { earthquake }\end{array}$ & 5159 & Polygon & $\begin{array}{l}\text { Remote sensing } \\
\text { (visual } \\
\text { interpretation) }\end{array}$ & Central Nepal & $\begin{array}{l}\text { Gurung and } \\
\text { Maharjan } \\
(2016)\end{array}$ \\
\hline $\begin{array}{l}\text { United States } \\
\text { Geological Survey } \\
\text { (USGS) }\end{array}$ & $\begin{array}{l}\text { After } 2015 \\
\text { Gorkha } \\
\text { earthquake }\end{array}$ & 24915 & Polygon & $\begin{array}{l}\text { Remote sensing } \\
\text { (visual } \\
\text { interpretation) }\end{array}$ & Central Nepal & $\begin{array}{l}\text { Roback et al. } \\
(2018)\end{array}$ \\
\hline $\begin{array}{l}\text { Indian Space } \\
\text { Research } \\
\text { Organisation } \\
\text { (ISRO) }\end{array}$ & $\begin{array}{l}\text { After } 2015 \\
\text { Gorkha } \\
\text { earthquake }\end{array}$ & 15551 & Polygon & $\begin{array}{l}\text { Remote sensing } \\
\text { (visual } \\
\text { interpretation) }\end{array}$ & Central Nepal & $\begin{array}{l}\text { Martha et al. } \\
\text { (2017) }\end{array}$ \\
\hline $\begin{array}{l}\text { Chinese Academy } \\
\text { of Sciences }\end{array}$ & $\begin{array}{l}\text { After } 2015 \\
\text { Gorkha } \\
\text { earthquake }\end{array}$ & 2645 & Polygon & $\begin{array}{l}\text { Remote sensing } \\
\text { (visual } \\
\text { interpretation) }\end{array}$ & Central Nepal & $\begin{array}{l}\text { Zhang et al. } \\
\text { (2016) }\end{array}$ \\
\hline $\begin{array}{l}\text { Faculty of } \\
\text { Geo-Information } \\
\text { Science and } \\
\text { Earth Observation } \\
\text { (ITC), University } \\
\text { of Twente }\end{array}$ & $\begin{array}{l}\text { After } 2015 \\
\text { Gorkha } \\
\text { earthquake }\end{array}$ & 2513 & Polygon & $\begin{array}{l}\text { Remote sensing } \\
\text { (visual } \\
\text { interpretation) }\end{array}$ & Central Nepal & $\begin{array}{l}\text { Meena et al. } \\
\text { (2018) }\end{array}$ \\
\hline
\end{tabular}


Table 1. Continued.

\begin{tabular}{|c|c|c|c|c|c|c|}
\hline $\begin{array}{l}\text { Producing } \\
\text { organisation }\end{array}$ & $\begin{array}{l}\text { Inventory } \\
\text { description }\end{array}$ & $\begin{array}{l}\text { No. of } \\
\text { landslides }\end{array}$ & Geometry type & $\begin{array}{l}\text { Method of } \\
\text { inventory } \\
\text { generation }\end{array}$ & Area coverage & Reference \\
\hline $\begin{array}{l}\text { The University } \\
\text { of Arizona, } \\
\text { Tucson, USA }\end{array}$ & $\begin{array}{l}\text { After } 2015 \\
\text { Gorkha } \\
\text { earthquake }\end{array}$ & 4312 & Polygon & $\begin{array}{l}\text { Remote sensing } \\
\text { (visual } \\
\text { interpretation) }\end{array}$ & Central Nepal & $\begin{array}{l}\text { Kargel et al. } \\
\text { (2016) }\end{array}$ \\
\hline $\begin{array}{l}\text { National } \\
\text { Aeronautics } \\
\text { and Space } \\
\text { Administration } \\
\text { (NASA) }\end{array}$ & $\begin{array}{l}\text { After } 2015 \\
\text { Gorkha } \\
\text { earthquake }\end{array}$ & NA & Point & $\begin{array}{l}\text { Harvesting of } \\
\text { digital news } \\
\text { articles and } \\
\text { remote } \\
\text { sensing (visual } \\
\text { interpretation) }\end{array}$ & $\begin{array}{l}\text { Global } \\
\text { landslide } \\
\text { database }\end{array}$ & $\begin{array}{l}\text { Juang et al. } \\
\text { (2019) }\end{array}$ \\
\hline
\end{tabular}

its dimensions, damage caused, the impacted area and sketch maps.

Some of the mentioned organisations have landslide inventories and socio-economic data for most of the districts, but the information is often only in analogue reports. However, the field reports are only available in an analogue format. Analogue reports are highly valuable; however, they are not as readily available as digital landslide information, and they are not accessible to a broad audience. There are maintenance reports by rural road department offices, which were created after road blockages. The DSCWM has prepared a landslide inventory, but landslide data are compiled into reports, and there is no geocoded information about the landslides.

EO-based landslide information is collected (Table 1) by several organisations in Nepal. The NDRR portal (http:// drrportal.gov.np/, last access: 15 December 2020), hosted by the Ministry of Home Affairs, was established in 2010 and includes information on landslides collected through field surveys as well as EO data. However, EO data hosted by the Ministry of Home Affairs could be used more intensively to complement the fieldwork done by expert organisations to update landslide information (e.g. regularly after the monsoon season) and consequently support disaster risk reduction in the country. NELIS can act as a platform to provide landslide information produced by various stakeholders using the EO data and field verifications from the Ministry of Home Affairs.

Additionally, newspaper and media reports can be a valuable source of landslide information in Nepal. A good example is the global landslide database of the National Aeronautics and Space Administration (NASA), which is based on news reports and scientific sources (Kirschbaum et al., 2010). News articles may be the first way by which people hear about a hazard. In Nepal, landslides near the road network or near the built-up area are sometimes covered by the newspaper and media agencies. Newspaper archives can give information about the damage caused by a landslide and the most probable landslide location near a locality or village.
Photos of the event shown in newspapers can provide information on the spatial extent of the landslide. In today's digital era, some newspapers in Nepal are also available online, enabling readers to find news articles from the past. Newspapers like The Himalayan Times, the most popular newspaper in Nepal, sometimes cover stories about landslides that affect populated areas or block rivers.

\subsubsection{Collecting new landslide data}

The previous section describes the used collection methods and existing landslide data for past landslides in Nepal. However, the stakeholders aim for a common approach to landslide collection that results in consistent landslide data across Nepal. This section's primary purpose is to provide indications for the use of techniques for collecting landslide data for NELIS. Despite the significance of landslide inventories and the way that landslide maps have been prepared for a long time, there are no clear guidelines for the creation of landslide maps and the assessment of their quality in Nepal. The selection of a specific mapping technique depends upon the purpose and the extent of the study area. Criteria for selecting mapping techniques include the mapping scale, the spatial resolution of the available remote sensing imagery, and most importantly the skills and resources available for completing the task (Guzzetti, 2000; Guzzetti et al., 2012; Van Westen et al., 2006).

Landslide features can be stored as a single feature with a point and polygon representing the landslide location. A landslide ID can be assigned to an individual landslide with associated attributes like the event's date, the resulting damage, the people affected and the landslide type, if such information is available. There can be variations among different datasets regarding their attributes. Based on expert opinion and literature, a set of essential attributes needs to be defined and used as a specification for a common landslide database. Hence, not all the primary databases' data will be transferred to the new NELIS database because of redundancy or false 
Table 2. Example of a landslide-mapping information sheet (DSCWM, 2016). VDC: village development committee. Ropani: unit of measurement equal to $94.05 \mathrm{~m}^{2}$ (https://www.ksmnepal.com/Post-Details/post/143/land-measurement-in-nepal, last access: 15 December 2020).

\begin{tabular}{llc|c}
\hline Name of district: Rasuwa & Name of VDC: Yarsa & Name of ward: Ghormu & Name of village: Tole \\
\hline Dimension of landslide & Length: $200 \mathrm{~m}$ & Width: 20 m \\
\hline Position on the hill & & Middle & \\
\hline Cracks in the land & Length & Width \\
\hline Impacted area: & & $2000 \mathrm{~m}^{2}$ & \\
\hline Potentially impacted area: & & $500 \mathrm{~m}^{2}$ & \\
\hline
\end{tabular}

Property in potentially impacted area
a. Farmland: Ropani
b. Settlement:
c. Road: $10 \mathrm{~m}$ Goreto Bato
d. Irrigation canal
e. Other property: water supply and water mill

\begin{tabular}{lcc|c}
\hline GPS coordinates & Longitude: 06232.93 & Latitude: 31002.24 & Elevation: $1748 \mathrm{~m}$ \\
\hline Sketch map of landslide & & & \\
& & & \\
& & \\
\hline Information collected by & Name of the person \\
\hline
\end{tabular}

information in the primary databases. Landslide attributes and the type of information will be taken from the Varnes classification (Varnes, 1978). Huang et al. (2013) propose another list of attributes with the primary attributes being landslide location, date and time of the event, type of landslide, and secondary attributes like triggering factors and damage. For the generation of new data, based on the Nepalese situation and data availability, there will be a linkage of spatial and metadata attributes to a single landslide polygon. The landslide at one location will get a unique landslide ID so that the new information or existing information from several data sources can be attached.

\subsection{User requirements}

During the interviews and open-questionnaire survey, several suggestions and requirements of the various stakeholders and organisations working in landslide research and mitigation were identified. The evaluation of the stakeholder's roles and requirements for NELIS showed that many suggestions resulted in NELIS development. The user requirement analysis revealed the components of NELIS that need to be prioritised during development. Four components are of most importance: a reporting system $(18 \%)$, the collection of new data from various sources after an event $(23.08 \%)$, the updating of already existing datasets $(32.98 \%)$ and the development of new guidelines for a mapping workflow (26.37\%). Survey results show that most mapping or data collection work has been carried out after the Gorkha event, but hardly any 
Table 3. Functionality and associated requirements requested by stakeholders.

\begin{tabular}{|c|c|c|c|c|c|c|c|c|}
\hline & $\begin{array}{l}\text { Department } \\
\text { of Soil } \\
\text { Conservation } \\
\text { and Watershed } \\
\text { Management } \\
\text { (DSCWM) }\end{array}$ & $\begin{array}{l}\text { Department } \\
\text { of Mines } \\
\text { and Geology } \\
\text { (DMG) }\end{array}$ & $\begin{array}{l}\text { Department } \\
\text { of Local } \\
\text { Infrastructure } \\
\text { Development } \\
\text { and } \\
\text { Agricultural } \\
\text { Roads } \\
\text { (DoLIDAR) }\end{array}$ & $\begin{array}{l}\text { Department } \\
\text { of Water } \\
\text { Induced } \\
\text { Disaster } \\
\text { Management } \\
\text { (DWIDM) }\end{array}$ & $\begin{array}{l}\text { Department } \\
\text { of Hydrology } \\
\text { and } \\
\text { Meteorology } \\
\text { (DHM) }\end{array}$ & $\begin{array}{l}\text { Village } \\
\text { development } \\
\text { committee } \\
\text { (VDC) }\end{array}$ & $\begin{array}{l}\text { International } \\
\text { organisations }\end{array}$ & $\begin{array}{l}\text { Academic } \\
\text { and } \\
\text { research } \\
\text { institutes }\end{array}$ \\
\hline $\begin{array}{l}\text { Landslide } \\
\text { data } \\
\text { collection }\end{array}$ & $\checkmark$ & $\checkmark$ & $\checkmark$ & $\checkmark$ & & & & \\
\hline $\begin{array}{l}\text { Guideline } \\
\text { preparation } \\
\text { for mapping } \\
\text { landslides }\end{array}$ & $\checkmark$ & & & $\checkmark$ & & & & $\checkmark$ \\
\hline $\begin{array}{l}\text { Digital } \\
\text { landslide } \\
\text { information } \\
\text { conversion } \\
\text { from } \\
\text { analogue } \\
\text { format } \\
\text { (reports) }\end{array}$ & & $\checkmark$ & $\checkmark$ & & $\checkmark$ & & $\checkmark$ & $\checkmark$ \\
\hline $\begin{array}{l}\text { Mitigation } \\
\text { works for } \\
\text { landslide } \\
\text { hazard } \\
\text { mitigation }\end{array}$ & $\checkmark$ & & $\checkmark$ & & $\checkmark$ & & & \\
\hline $\begin{array}{l}\text { Local- and } \\
\text { regional- } \\
\text { level } \\
\text { landslide } \\
\text { information } \\
\text { gathering }\end{array}$ & & $\checkmark$ & $\checkmark$ & & & $\checkmark$ & & $\checkmark$ \\
\hline $\begin{array}{l}\text { Human } \\
\text { resource } \\
\text { support }\end{array}$ & $\checkmark$ & $\checkmark$ & $\checkmark$ & $\checkmark$ & $\checkmark$ & & $\checkmark$ & $\checkmark$ \\
\hline
\end{tabular}

updates to the datasets were made afterwards. It also became evident that landslide inventory data are not available to the public, and it is difficult to get permissions from authors to share the data with external scientists or organisations. The further analysis of the questionnaire's open questions identified particular functionality and associated requirements that the stakeholders expect that NELIS should support (Table 3).

From the questionnaire responses and the personal interviews conducted with stakeholders, NELIS's common objective could be synthesised: NELIS shall support coordinated landslide action in Nepal and the development of a consistent landslide database that is widely accessible. When developing a comprehensive landslide inventory, there are two main questions: first, how to deal with new information to be collected about landslide events in the future and, second, how to deal with available information about past landslide events. After finding answers to these two questions, the third question is how to enable widely accepted usage of the resulting comprehensive landslide inventory.

Based on the questionnaire survey and the interviews, the following user needs and requirements for the development of NELIS were compiled:

i. There is a need for general guidelines for coordinated documentation of new landslides, and coordination among organisations is necessary to avoid duplication of efforts.

ii. The guidelines should be built on existing mapping guidelines of, for example, the DSCWM and DMG to ensure compatibility with landslide information.

iii. The landslide inventory should be regularly updated, at least after each monsoon season. 
iv. NELIS should exploit both EO and field data collection advantages in generating comprehensive and reliable landslide information. Additionally, NELIS should be open to methodological advancements from research in the landslide hazard domain.

v. Stakeholders and users from different domains should be able to provide landslide information.

vi. There is a need for a platform that supports the documentation process of new landslides.

vii. The platform should allow for the integration of existing datasets (digital data and analogue reports).

viii. The platform shall allow users to perform a comparative analysis of landslide information with different background layers such as land use, settlements and geology and export the analysis results.

Requirements and suggestions should be included in NELIS development, considering any technical and management limitations at the national level. Based on the user requirements, a conceptual structure of NELIS is proposed.

\subsection{The database structure of NELIS}

NELIS shall allow for accessing, storing, displaying, querying and adding landslide data, while considering standard guidelines and standardised workflows. The existing landslide datasets from different sources have various structures and types, making it challenging to transfer and compare the data. Moreover, landslide datasets show different scales and accuracy levels. Therefore, a unified data model for landslide storage is needed. There is a need for the development of guidelines for data provision following a defined structure. NELIS is proposed to have a series of views and tables in a relational spatial database. The location and shape of landslides represent the spatial information. The database should be designed to store landslide information as polygon and point features and information related to the projection system. Landslide information from analogue technical reports needs to be transferred to a digital format with geocoded information and then uploaded to NELIS.

The communities can directly report landslides into the system. NELIS will allow users to participate in the mapping process by pointing out a landslide and adding metadata, if available, on the web-based platform. After reporting, the information will be stored in a temporary database. There could be false information entered by non-experts, and thus, a landslide expert should check the data at the district level before publication. There is a landslide expert at every district headquarter, and this expert can be the person responsible for validating the landslides reported by the public.

After implementing NELIS, officers from governmental organisations should be given training regarding the use of

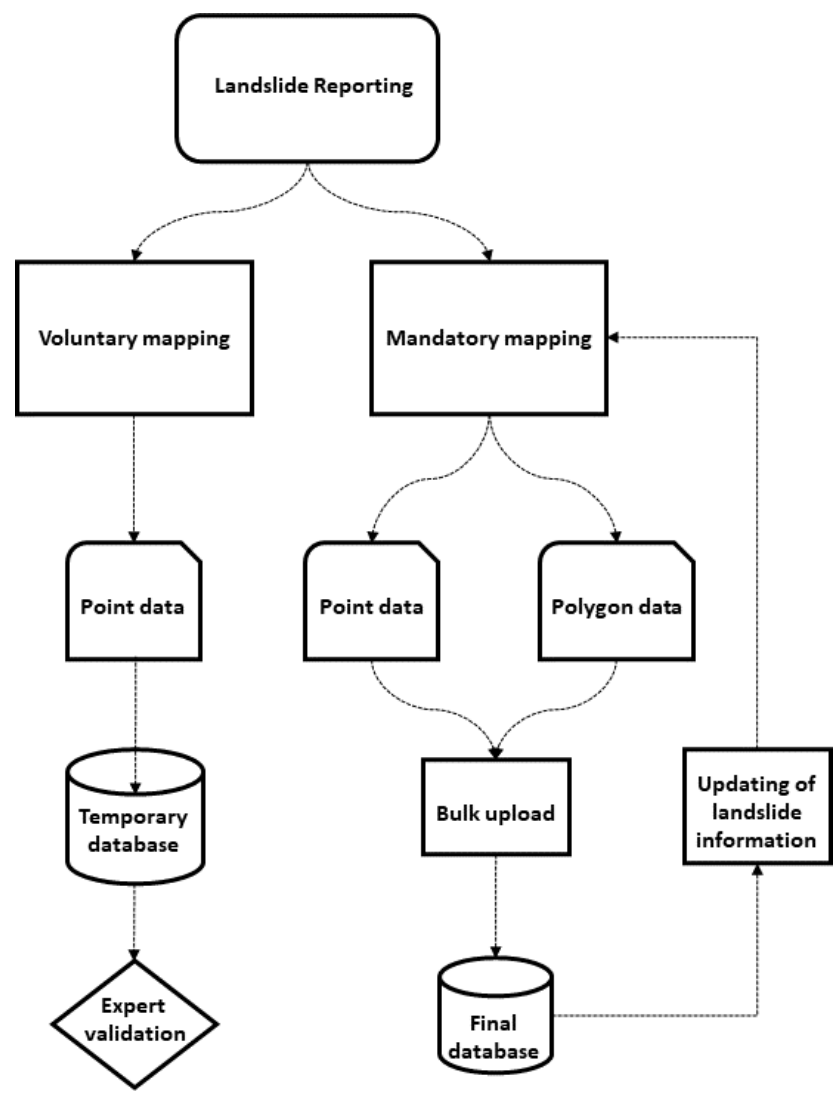

Figure 3. The workflow for reporting landslides.

the system and the management of the information from different sources. Experts can also transfer bulk data directly to the system, as both point and polygon data (see Fig. 3).

The web service platform can be implemented as a spatial relational database, application code, a web server, etc. and can be hosted, developed and maintained by related organisations in Nepal. The web interface functionality comprises tools for searching and displaying landslide information in the form of map views and tables. This allows the user to interact with the information and map layers (Rosser et al., 2017). An advantage of the proposed concept for NELIS is that it is exclusively based on open-source software. The object-relational database management system (DBMS) will be based on PostGIS, providing all SQL (Structured Query Language) functions as a database language for generation and manipulation of stored data and data queries. To process and store spatial data, PostGIS can be integrated as an extension for PostgreSQL. PostGIS improves the storage of GIS information in the DBMS and offers spatial operations, spatial functions, spatial data types and a spatial indexing enhancement (Obe and Hsu, 2011).

The first and foremost step is collecting new data and importing analogue reports and existing digital databases by a landslide expert. Then the data need to be transferred to vector or raster layers for further analysis (see Fig. 4). After that, 


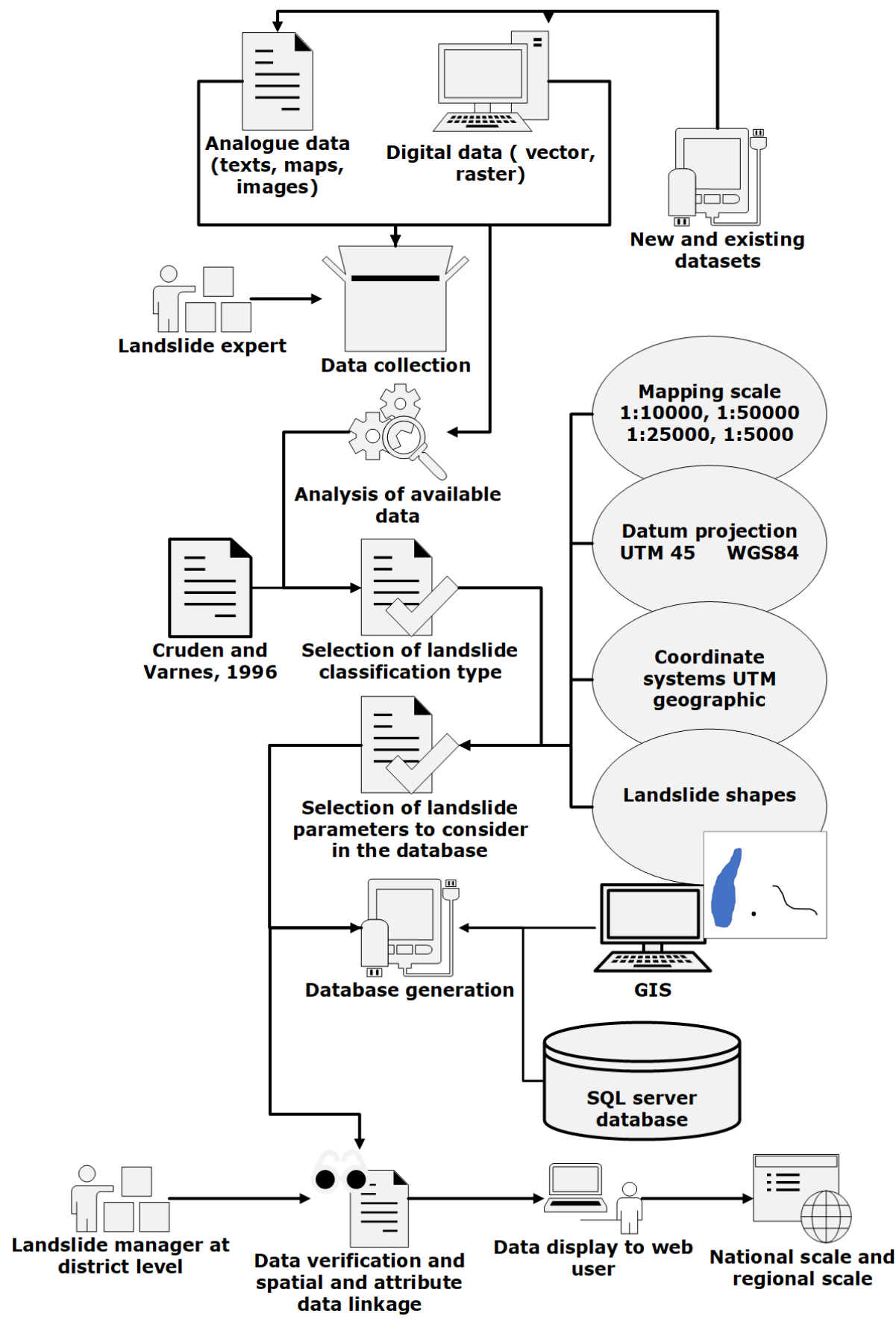

Figure 4. The workflow of NELIS; adapted from Devoli et al. (2007).

the available landslide data can be classified into different landslide types based on the approach of landslide classification by Cruden and Varnes (1996) and Hungr et al. (2014). In the next step, data are stored in a database. Finally, landslide managers will verify the landslides in their respective areas, and after the final check, data can be uploaded to the web-based system to be available online.

\section{Conclusions}

The development of NELIS to report and arrange landslide data will facilitate better data sharing among stakeholders and will provide a platform with comprehensive landslide information to support future risk mitigation efforts. Any produced landslide inventory cannot be fully complete or entirely accurate. The quality of the data in NELIS will be dependent on the quality and completeness of data recorded 
in the source database. Many landslide records only store point-based location information, with no information on the landslide area, movement date, type of landslide or triggering event.

One of the data's limitations to be integrated into the common NELIS landslide database is the inconsistency of the spatial accuracy of landslide points and polygons, which depends on several factors such as the original method and scale of mapping and the skills of the interpreter. Generally, landslide polygons delineated from satellite imagery are accurate at the scale at which they are delineated or portrayed, while the absolute accuracy may be limited. Landslide point location accuracy is highly variable and ranges from sub-metre to centimetre precision as measured by GPS devices. Often it is even impossible to reach landslides to take on-site GPS measurements.

Landslide inventories also show limitations as a result of the landslide-mapping method applied. A comprehensive landslide database at a central platform allows for better characterisation of landslides by relating them to a particular triggering event such as heavy rainfall or an earthquake in a particular area and, consequently, facilitates the estimation of the damages and impacts. Such information is useful for land-use planners and policymakers for managing landslide hazards and associated environmental impacts.

This study shows the available landslide information in Nepal and identifies the stakeholders involved in landslide risk management. This knowledge was used to propose a conceptual framework for NELIS, including a potential design and workflow structure. The system can be beneficial for specifying the potential risky regions and, consequently, developing risk mitigation strategies. The next step can be the practical implementation of the conceptual framework to support landslide action in Nepal.

Data availability. All the information used including questionnaire questions is already included in the paper.

Author contributions. SRM initiated this work, carried out the field survey and wrote the paper with contributions from all authors. The results and conceptual framework were framed by SRM, FA and DH. SRM wrote the paper in consultation with OG and TB. All authors participated in improving the revised version of the paper.

Competing interests. The authors declare that they have no conflict of interest.

Acknowledgements. Florian Albrecht and Daniel Hölbling have been partly supported by the Austrian Research Promotion Agency (FFG) in the Austrian Space Applications Programme (ASAP) through the projects "Land@Slide" (EObased landslide mapping: from methodological developments to automated web-based information delivery; contract no. 847970) and MontEO (The impact of mass movements on alpine trails and huts assessed by EO data; contract no. 873667).

Financial support. This research has been supported by the Austrian Science Fund (grant no. DK W 1237-N23).

Review statement. This paper was edited by Thomas Glade and reviewed by Stefan Jaeger and one anonymous referee.

\section{References}

Albrecht, F., Hölbling, D., Weinke, E., and Eisank, C.: User requirements for an Earth Observation (EO)-based landslide information web service, Landslides and Engineered Slopes, in: Experience, Theory and Practice, CRC Press, London, 301-308, 2016.

Bhandari, D. and Hodder, C.: Learning from Nepal NRA to inform the National Disaster Risk Reduction and Management Authority, Oxford Policy Management, Kathmandu, 2019.

Bisri, M. B. F. and Beniya, S.: Analysing the national disaster response framework and inter-organisational network of the 2015 Nepal/Gorkha earthquake, Procedia Eng., 159, 19-26, 2016.

Carr, J. A.: Pre-disaster integration of community emergency response teams within local emergency management systems, North Dakota State University, Fargo, North Dakota, 2014.

Centre for Research on the Epidemiology of Disasters - CRED, available at: http://www.emdat.be/about (last access: 15 December 2020), 2018

Chen, W., He, B., Zhang, L., and Nover, D.: Developing an integrated 2D and 3D WebGIS-based platform for effective landslide hazard management, Int. J. Disast. Risk Reduct., 20, 26-38, 2016.

Cheng, D., Cui, Y., Su, F., Jia, Y., and Choi, C. E.: The characteristics of the Mocoa compound disaster event, Colombia, Landslides, 15, 1223-1232, https://doi.org/10.1007/s10346-0180969-1, 2018.

Cruden, D. M., Varnes, D. J.: Landslide Types and Processes, Transportation Research Board, Special Report 247, US National Academy of Sciences, Washington, D.C., USA, 36-75, 1996.

De Donatis, M. and Bruciatelli, L.: MAP IT: The GIS software for field mapping with tablet pc, Comput. Geosci., 32, 673-680, https://doi.org/10.1016/j.cageo.2005.09.003, 2006.

Devkota, S., Sudmeier-Rieux, K., Penna, I., Eberle, S., Jaboyedoff, M., Adhikari, A., and Khanal, R.: Community-based bioengineering for eco-safe roadsides in Nepal, University of Lausanne, Lausanne, International Union for Conservation of Nature, Nepal and Department of Soil Conservation and Watershed Management, Government of Nepal, Nepal, 2014.

Devoli, G., Strauch, W., Chávez, G., and Høeg, K.: A landslide database for Nicaragua: a tool for landslide-hazard management, Landslides, 4, 163-176, 2007.

Dikshit, A., Sarkar, R., Pradhan, B., Segoni, S., and Alamri, A. M.: Rainfall Induced Landslide Studies in Indian Himalayan Region: A Critical Review, Appl. Sci., 10, 2466, https://doi.org/10.3390/app10072466, 2020. 
DSCWM: Landslide Area Mapping of Lower Phalakhu Khola Subwatershed of Rasuwa District, District Soil Conservation Office, Kathmandu, Nepal, 2016.

Fang, Z., Wang, Y., Peng, L., and Hong, H.: Integration of convolutional neural network and conventional machine learning classifiers for landslide susceptibility mapping, Comput. Geosci., 139, 104470, https://doi.org/10.1016/j.cageo.2020.104470, 2020.

Ghorbanzadeh, O., Blaschke, T., Gholamnia, K., Meena, S. R., Tiede, D., and Aryal, J.: Evaluation of Different Machine Learning Methods and Deep-Learning Convolutional Neural Networks for Landslide Detection, Remote Sens., 11, 196, https://doi.org/10.3390/rs11020196, 2019a.

Ghorbanzadeh, O., Meena, S. R., Blaschke, T., and Aryal, J.: UAV-Based Slope Failure Detection Using Deep-Learning Convolutional Neural Networks, Remote Sens., 11, 2046, https://doi.org/10.3390/rs11172046, 2019b.

Gnyawali, K. R., Maka, S., Adhikari, B. R., Chamlagain, D., Duwal, S., and Dhungana, A. R.: Spatial implications of earthquake induced landslides triggered by the April 25 Gorkha earthquake $M_{\mathrm{W}}$ 7.8: preliminary analysis and findings, International conference on earthquake engineering and post disastor reconstruction planning, 24-26 April 2016, Bhaktapur, Nepal, 50-58, 2016.

Gurung, D. R. and Maharjan, S. B.: Post Nepal Earthquake Landslide Inventory, Landslide data of 14 earthquake affected districts of Nepal [Data set], ICIMOD, Kathmandu, Nepa, 28-29, https://doi.org/10.26066/RDS.31016, 2016.

Guzzetti, F.: Landslide fatalities and the evaluation of landslide risk in Italy, Eng. Geol., 58, 89-107, 2000.

Guzzetti, F., Cardinali, M., and Reichenbach, P.: The AVI project: A bibliographical and archive inventory of landslides and floods in Italy, Environ. Manage., 18, 623-633, https://doi.org/10.1007/bf02400865, 1994.

Guzzetti, F., Mondini, A. C., Cardinali, M., Fiorucci, F., Santangelo, M., and Chang, K.-T.: Landslide inventory maps: New tools for an old problem, Earth-Sci. Rev., 112, 42-66, 2012.

Hasegawa, S., Dahal, R. K., Yamanaka, M., Bhandary, N. P., Yatabe, R., and Inagaki, H.: Causes of large-scale landslides in the Lesser Himalaya of central Nepal, Environ. Geol., 57, 14231434, https://doi.org/10.1007/s00254-008-1420-z, 2009.

Herrera, G., Mateos, R. M., García-Davalillo, J. C., Grandjean, G., Poyiadji, E., Maftei, R., Filipciuc, T.-C., Jemec Auflič, M., Jež, J., Podolszki, L., Trigila, A., Iadanza, C., Raetzo, H., Kociu, A., Przyłucka, M., Kułak, M., Sheehy, M., Pellicer, X. M., McKeown, C., Ryan, G., Kopačková, V., Frei, M., Kuhn, D., Hermanns, R. L., Koulermou, N., Smith, C. A., Engdahl, M., Buxó, P., Gonzalez, M., Dashwood, C., Reeves, H., Cigna, F., Liščák, P., Pauditš, P., Mikulènas, V., Demir, V., Raha, M., Quental, L., Sandić, C., Fusi, B., and Jensen, O. A.: Landslide databases in the Geological Surveys of Europe, Landslides, 15, 359-379, https://doi.org/10.1007/s10346-017-0902-z, 2018.

Hölbling, D., Füreder, P., Antolini, F., Cigna, F., Casagli, N., and Lang, S.: A Semi-Automated Object-Based Approach for Landslide Detection Validated by Persistent Scatterer Interferometry Measures and Landslide Inventories, Remote Sens., 4, 13101336, 2012.

Hölbling, D., Weinke, E., Albrecht, F. T., Eisank, C., Vecchiotti, F., Friedl, B., Osberger, A., and Kociu, A.: A web service for landslide mapping based on Earth Observation data, in: Proceedings of the 3rd Regional symposium on Landslides in the Adriatic-
Balkan Region (ReSyLAB), 11-13 June 2017, Ljubljana, Slovenia, 137-142, 2018.

Huang, R., Huang, J., Ju, N., He, C., and Li, W.: WebGIS-based information management system for landslides triggered by Wenchuan earthquake, Nat. Hazards, 65, 1507-1517, 2013.

Hungr, O., Leroueil, S., and Picarelli, L.: The Varnes classification of landslide types, an update, Landslides, 11, 167-194, https://doi.org/10.1007/s10346-013-0436-y, 2014.

Jaiswal, P. and van Westen, C. J.: Use of quantitative landslide hazard and risk information for local disaster risk reduction along a transportation corridor: A case study from Nilgiri district, India, Nat. Hazards, 65, 887-913, https://doi.org/10.1007/s11069-0120404-1, 2013.

Juang, C. S., Stanley, T. A., and Kirschbaum, D. B.: Using citizen science to expand the global map of landslides: Introducing the Cooperative Open Online Landslide Repository (COOLR), PLOS ONE, 14, e0218657, https://doi.org/10.1371/journal.pone.0218657, 2019.

Kargel, J. S., Leonard, G. J., Shugar, D. H., Haritashya, U. K., Bevington, A., Fielding, E. J., Fujita, K., Geertsema, M., Miles, E. S., Steiner, J., Anderson, E., Bajracharya, S., Bawden, G. W., Breashears, D. F., Byers, A., Collins, B., Dhital, M. R., Donnellan, A., Evans, T. L., Geai, M. L., Glasscoe, M. T., Green, D., Gurung, D. R., Heijenk, R., Hilborn, A., Hudnut, K., Huyck, C., Immerzeel, W. W., Liming, J., Jibson, R., Kaab, A., Khanal, N. R., Kirschbaum, D., Kraaijenbrink, P. D., Lamsal, D., Shiyin, L., Mingyang, L., McKinney, D., Nahirnick, N. K., Zhuotong, N., Ojha, S., Olsenholler, J., Painter, T. H., Pleasants, M., Pratima, K. C., Yuan, Q. I., Raup, B. H., Regmi, D., Rounce, D. R., Sakai, A., Donghui, S., Shea, J. M., Shrestha, A. B., Shukla, A., Stumm, D., van der Kooij, M., Voss, K., Xin, W., Weihs, B., Wolfe, D., Lizong, W., Xiaojun, Y., Yoder, M. R., and Young, N.: Geomorphic and geologic controls of geohazards induced by Nepal's 2015 Gorkha earthquake, Science, 351, aac8353, https://doi.org/10.1126/science.aac8353, 2016.

Kirschbaum, D. B., Adler, R., Hong, Y., Hill, S., and Lerner-Lam, A.: A global landslide catalog for hazard applications: method, results, and limitations, Nat. Hazards, 52, 561-575, 2010.

Klose, M., Gruber, D., Damm, B., and Gerold, G.: Spatial databases and GIS as tools for regional landslide susceptibility modeling, Z. Geomorphol., 58, 1-36, https://doi.org/10.1127/03728854/2013/0119, 2014.

Knoop, P. A. and van der Pluijm, B.: GeoPad: Tablet PC-enabled Field Science Education, in: The Impact of Pen-based Technology on Education: Vignettes, Evaluations, and Future Directions, edited by: Berque, D., Prey, J., and Reed, R., Purdue University Press, West Lafayette, Indiana, USA, 200 pp., 2006.

Lazzari, M., Gioia, D., and Anzidei, B.: Landslide inventory of the Basilicata region (Southern Italy), J. Maps, 14, 348-356, 2018.

Linkha, T. R.: Disasters: Spatio-Temporal Distribution of Dhankuta District, Nepal, Rupantaran, 3, 93-107, 2020.

Malamud, B. D., Turcotte, D. L., Guzzetti, F., and Reichenbach, P.: Landslide inventories and their statistical properties, Earth Surf. Proc. Land., 29, 687-711, 2004.

Martha, T. R., Roy, P., Mazumdar, R., Govindharaj, K. B., and Kumar, K. V.: Spatial characteristics of landslides triggered by the $2015 M_{\mathrm{W}} 7.8$ (Gorkha) and $M_{\mathrm{W}} 7.3$ (Dolakha) earthquakes in Nepal, Landslides, 14, 697-704, 2017. 
Meena, S. R. and Tavakkoli Piralilou, S.: Comparison of Earthquake-Triggered Landslide Inventories: A Case Study of the 2015 Gorkha Earthquake, Nepal, Geosciences, 9, 437, https://doi.org/10.3390/geosciences9100437, 2019.

Meena, S. R., Mavrouli, O., and Westen, C. J.: Web based landslide management system for Nepal, in: 33rd Himalaya-KarakorumTibet Workshop (HKT), 10-12 September 2018, Lausanne, Switzerland, 2018.

Meena, S. R., Ghorbanzadeh, O., and Blaschke, T.: A Comparative Study of Statistics-Based Landslide Susceptibility Models: A Case Study of the Region Affected by the Gorkha Earthquake in Nepal, ISPRS Int. J. Geoinf., 8, 94, https://doi.org/10.3390/ijgi8020094, 2019.

Nepal Earthquake - Humanitarian Data Exchange, available at: https://data.humdata.org/group/nepal-earthquake (last access: 15 December 2020), 2015.

Nepal, P., Khanal, N. R., and Sharma, B. P. P.: Policies and institutions for disaster risk management in Nepal: A review, Geogr. J. Nepal, 11, 1-24, 2018.

Obe, R. O. and Hsu, L. S.: PostGIS in Action, 2nd ed., Manning Publications Co., Greenwich, CT, USA, 520-520, 2011.

Panwar, V. and Sen, S.: Disaster Damage Records of EM-DAT and DesInventar: A Systematic Comparison, Econom. Disast. Clim. Change, 4, 295-317, https://doi.org/10.1007/s41885-019-000520, 2020.

Pennington, C., Freeborough, K., Dashwood, C., Dijkstra, T., and Lawrie, K.: The National Landslide Database of Great Britain: Acquisition, communication and the role of social media, Geomorphology, 249, 44-51, 2015.

Pokharel, P. and Bhuju, D. R.: Pre Earthquake Nationwide Landslide Inventory of Nepal: An Academic Exercise, ICIMOD, Kathmandu, Nepal, 2015.

Regmi, A. D., Dhital, M. R., Zhang, J.-Q., Su, L.-J., and Chen, X.Q.: Landslide susceptibility assessment of the region affected by the 25 April 2015 Gorkha earthquake of Nepal, J. Mt. Sci., 13, 1941-1957, 2016.

Roback, K., Clark, M. K., West, A. J., Zekkos, D., Li, G., Gallen, S. F., Chamlagain, D., and Godt, J. W.: The size, distribution, and mobility of landslides caused by the $2015 M_{\mathrm{W}} 7.8$ Gorkha earthquake, Nepal, Geomorphology, 301, 121-138, 2018.

Robinson, T. R., Rosser, N. J., Densmore, A. L., Williams, J. G., Kincey, M. E., Benjamin, J., and Bell, H. J. A.: Rapid postearthquake modelling of coseismic landslide intensity and distribution for emergency response decision support, Nat. Hazards Earth Syst. Sci., 17, 1521-1540, https://doi.org/10.5194/nhess17-1521-2017, 2017

Rosser, B., Dellow, S., Haubrock, S., and Glassey, P.: New Zealand's national landslide database, Landslides, 14, 1949_ 1959, 2017.

Rossi, G., Tanteri, L., Tofani, V., Vannocci, P., Moretti, S., and Casagli, N.: Multitemporal UAV surveys for landslide mapping and characterisation, Landslides, 15, 1045-1052, https://doi.org/10.1007/s10346-018-0978-0, 2018.

Saffer, D.: Designing for Interaction: Creating Smart Applications and Clever Devices, 2007, New Riders Press, 2, 2.1, available at: http://www.designingforinteraction.com (last access: 15 December 2020), 2017.

Secretariat, C. A. and Durbar, S.: Constitution of Nepal 2015, Constituent Assembly Secretariat, Kathmandu, Nepal, 2015.
Sharma, E., Molden, D., Rahman, A., Khatiwada, Y. R., Zhang, L., Singh, S. P., Yao, T., and Wester, P.: Introduction to the Hindu Kush Himalaya Assessment, in: The Hindu Kush Himalaya Assessment, edited by: Wester, P., Mishra, A., Mukherji, A., and Shrestha, A. B., Springer International Publishing, Cham, 1-16, 2019.

Suwal, D., and Panday, U. S.: UAV for Post-Disaster Quick Assessment, FIG - ISPRS workshop, 2015: International Workshop on Strengthening Opportunity for Professional Development \& Spatial Data Infrastructure Development, 25-27 November 2015, Kathmandu, Nepal, 2015.

Tsou, C.-Y., Chigira, M., Higaki, D., Sato, G., Yagi, H., Sato, H. P., Wakai, A., Dangol, V., Amatya, S. C., and Yatagai, A.: Topographic and geologic controls on landslides induced by the 2015 Gorkha earthquake and its aftershocks: an example from the Trishuli Valley, Central Nepal, Landslides, 15, 953-965, https://doi.org/10.1007/s10346-017-0913-9, 2018.

Tavakkoli Piralilou, S., Shahabi, H., Jarihani, B., Ghorbanzadeh, O., Blaschke, T., Gholamnia, K., Meena, S. R., and Aryal, J.: Landslide Detection Using Multi-Scale Image Segmentation and Different Machine Learning Models in the Higher Himalayas, Remote Sens., 11, 2575, https://doi.org/10.3390/rs11212575, 2019.

Valagussa, A., Frattini, P., Crosta, G., and Valbuzzi, E.: Pre and post 2015 Nepal earthquake landslide inventories, in: Landslides and Engineered Slopes. Experience, Theory and Practice, CRC Press, London, 1957-1964, 2016.

Van Den Eeckhaut, M. and Hervás, J.: State of the art of national landslide databases in Europe and their potential for assessing landslide susceptibility, hazard and risk, Geomorphology, 139140, 545-558, https://doi.org/10.1016/j.geomorph.2011.12.006, 2012.

Van Westen, C., Van Asch, T. W., and Soeters, R.: Landslide hazard and risk zonation - why is it still so difficult?, Bull. Eng. Geol. Environ., 65, 167-184, 2006.

Varnes, D. J.: Slope Movement Types and Processes, Transportation Research Board Special Report, in: Special report 176: Landslides: Analysis and Control, Transportation Research Board, Washington, D.C., 11-33, 1978.

Vij, S., Russell, C., Clark, J., Parajuli, B. P., Shakya, P., and Dewulf, A.: Evolving disaster governance paradigms in Nepal, Int. J. Disast. Risk Reduct., 50, 101911, https://doi.org/10.1016/j.ijdrr.2020.101911, 2020.

Watson, I.: Resilience and disaster risk reduction: reclassifying diversity and national identity in post-earthquake Nepal, Third World Q., 38, 483-504, 2017.

Wealands, K., Benda, P., Miller, S., and Cartwright, W. E.: User Assessment as Input for Useful Geospatial Representations within Mobile Location-Based Services, Trans. GIS, 11, 283-309, 2007.

$\mathrm{Xu}, \mathrm{C} ., \mathrm{Xu}, \mathrm{X}$., and Shyu, J. B. H.: Database and spatial distribution of landslides triggered by the Lushan, China $M_{\mathrm{W}} 6.6$ earthquake of 20 April 2013, Geomorphology, 248, 77-92, 2015.

Xu, C., Tian, Y., Zhou, B., Ran, H., and Lyu, G.: Landslide damage along Araniko highway and Pasang Lhamu highway and regional assessment of landslide hazard related to the Gorkha, Nepal earthquake of 25 April 2015, Geoenviron. Disast., 4, 14, https://doi.org/10.1186/s40677-017-0078-9, 2017. 
Zhang, J., van Westen, C. J., Tanyas, H., Mavrouli, O., Ge, Y., Bajrachary, S., Gurung, D. R., Dhital, M. R., and Khanal, N. R.: How size and trigger matter: analyzing rainfall- and earthquake-triggered landslide inventories and their causal relation in the Koshi River basin, central Himalaya, Nat. Hazards Earth Syst. Sci., 19, 1789-1805, https://doi.org/10.5194/nhess19-1789-2019, 2019.
Zhang, J. Q., Liu, R. k., Deng, W., Khanal, N. R., Gurung, D. R., Murthy, M. S. R., and Wahid, S.: Characteristics of landslide in Koshi River Basin, Central Himalaya, J. Mt. Sci., 13, 1711-1722, https://doi.org/10.1007/s11629-016-4017-0, 2016. 